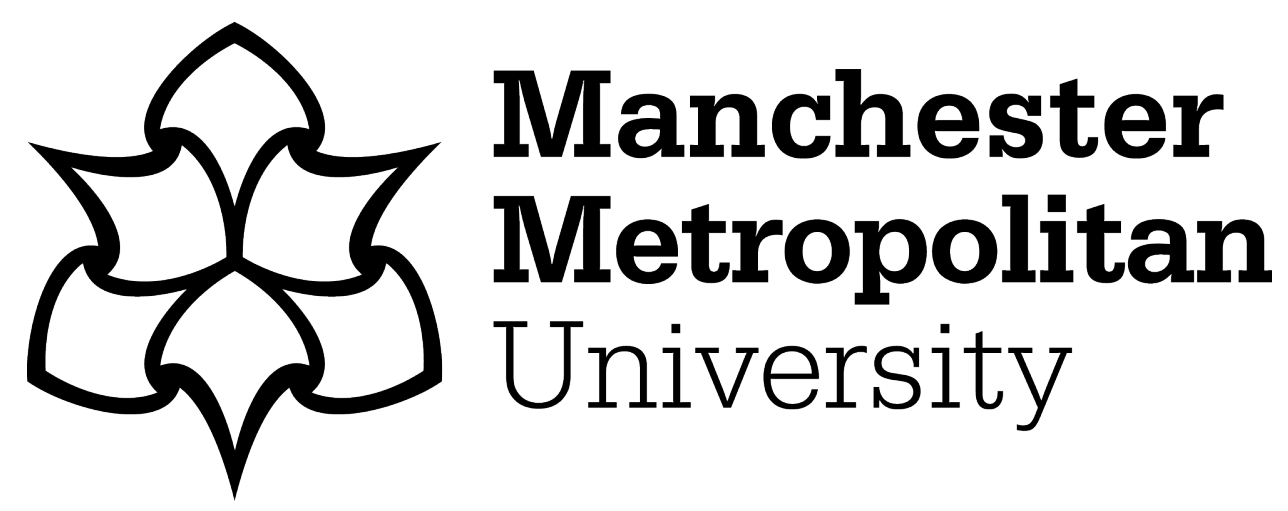

Gao, Zhaohe, Kulczyk-Malecka, Justyna ORCID logoORCID: https://orcid.org/0000-0002-4905-3635, Bousser, Etienne, Zhang, Xun, Chen, Ying, Liu, Han, Kelly, Peter ORCID logoORCID: https://orcid.org/00000003-1008-4941 and Xiao, Ping (2019) Sputter-deposited nitrides for oxidation protection in a steam environment at high temperatures. Thin Solid Films, 688. p. 137439. ISSN 0040-6090

Downloaded from: https://e-space.mmu.ac.uk/623586/

Version: Accepted Version

Publisher: Elsevier BV

DOI: https://doi.org/10.1016/j.tsf.2019.137439

Usage rights: Creative Commons: Attribution-Noncommercial-No Derivative Works 4.0

Please cite the published version 


\title{
Sputter-deposited nitrides for oxidation protection in a steam environment at high temperatures.
}

Zhaohe Gao ${ }^{\mathrm{a}}$, Justyna Kulczyk-Malecka ${ }^{\mathrm{b}}$, Etienne Bousser ${ }^{\mathrm{a}}$, Xun Zhang ${ }^{\mathrm{a}}$, Ying Chen ${ }^{\mathrm{a}}$, Han Liu $^{\mathrm{a}}$, Peter Kelly ${ }^{\mathrm{b}}$ and Ping Xiao ${ }^{\mathrm{a}}$

${ }^{a}$ School of Materials, University of Manchester, Manchester UK, M13 9PL, UK

${ }^{b}$ Surface Engineering Group, Manchester Fuel Cell Innovation Centre, Manchester Metropolitan University, Manchester, M1 5GD, UK

\begin{abstract}
The oxidation behaviours of $\mathrm{ZrN}$, TiN and $\mathrm{TiSiN}$ in a steam environment in the high temperature range of $600-900^{\circ} \mathrm{C}$ have been studied and compared. Nitride coatings were deposited by reactive magnetron sputtering onto Zirc - alloy and silicon wafer substrates. The steam oxidation test was performed in order to investigate oxidation resistance in the Loss - of - Coolant Accident (LOCA) scenario in Light Water Reactor applications. It was found that TiSiN showed better oxidation resistance in a steam environment than $\mathrm{ZrN}$ and $\mathrm{TiN}$. Coatings in the as-deposited state and after thermal exposure were characterised using focused ion beam, transmission electron microscopy and X-ray diffraction to evaluate microstructure and phases present in the coatings.
\end{abstract}

Key words: Steam oxidation; Zirconium nitride; Titanium nitride; Titanium silicon nitride; Magnetron sputtering; Loss-of-coolant accident

\section{Introduction}

The nuclear disaster that occurred in the Fukushima Daiichi Power Plant in March 2011 has opened a new route for thin solid film applications. Oxidation-resistant coatings have been 
applied on zirconium fuel cladding to mitigate the failure mechanism in case of a Loss-ofCoolant accident (LOCA). When LOCA occurs, zirconium cladding rapidly reacts with high temperature steam generated by the fission product decay heat trapped inside the nuclear reactor [1-2]. Hydrogen gas, the reaction by-product, is highly flammable and upon ignition can lead to explosion. Several authors have studied the degradation of cladding material, such as Zircaloy-4, ZIRLO ${ }^{\mathrm{TM}}$ and $\mathrm{M}^{\circledR}{ }^{\circledR}$ in high temperature oxygen, nitrogen, air and steam environments showing that the cladding materials degrade fast with the formation of nonprotective oxide scales [3-5].

To mitigate LOCA occurrences coatings that are thermally stable, thermally conductive, well - adhered to the metal substrate, mechanically robust and have a low neutron capture cross section have been considered. For high temperature applications, thermal mismatch between the coating and the substrate should be minimised to reduce the residual stress in the coating. Furthermore, the coating must be chemically compatible with the substrate to avoid excessive interdiffusion or the formation of brittle intermetallics between both at high temperature. [69]. To date, a few metallic (e.g. $\mathrm{Cr}, \mathrm{FeCrAlY}, \mathrm{Al}_{3} \mathrm{Ti}$ ) and ceramic (e.g. $\mathrm{Ti}_{2} \mathrm{SiC}, \mathrm{TiN}, \mathrm{Cr}_{2} \mathrm{C}_{3}$ ) coatings have been deposited on zirconium alloys and tested in different environments $[1,10$ 13]. The results showed that the oxidation rate of zirconium alloys in air and steam had been reduced and it has been pointed out that protective coatings containing $\mathrm{Cr}$, $\mathrm{Al}$ or $\mathrm{Si}$ form protective oxide layers upon oxidation [14-17]. Nitride coatings have been considered for these applications due to their good oxidation resistance, high thermal conductivity and low neutron capture cross-section [18-24]. It was reported that the oxidation of binary $\mathrm{ZrN}$ and $\mathrm{TiN}$ coatings occurred drastically at $500^{\circ} \mathrm{C}-600^{\circ} \mathrm{C}$ in air [25-26], whereas the same process occurs for binary AlN and $\mathrm{CrN}$ nitrides at $700^{\circ} \mathrm{C}-800^{\circ} \mathrm{C}$ in air [27]. The oxidation resistance of these binary coatings can be promoted by adding third elements such as Al, Y, or Si [28-30]. For instance, addition of $\mathrm{Y}$ element into $\mathrm{ZrN}$ could stabilize the $\mathrm{t}-\mathrm{ZrO}_{2}$ formed on $\mathrm{ZrN}$ and thereby result in 
fewer micro-cracks across the $\mathrm{ZrO}_{2}$ oxide scale, which has been found to improve the oxidation resistance of $\mathrm{ZrN}$ [31]. The addition of $\mathrm{Si}$ into the binary nitride coating leads to the formation of an amorphous $\mathrm{Si}_{3} \mathrm{~N}_{4}$ phase, which exhibits a relatively higher thermal stability and higher oxidation resistance than that of $\mathrm{MeN}(\mathrm{Me}=\mathrm{Ti}, \mathrm{Zr}, \mathrm{Cr}$, etc.) [21, 32-33]. For example, a nitride coating consisting of $\mathrm{TiN}$ phase combined with $\mathrm{Si}_{3} \mathrm{~N}_{4}$ phase was found to be thermally stable up to $1000^{\circ} \mathrm{C}$ in an air environment. In a nitride coating with $\mathrm{Si}$ content $<10$ at $\%$, the $\mathrm{MeN}(\mathrm{Me}=\mathrm{Zr}, \mathrm{Ti}, \mathrm{V})$ grains are partially surrounded by amorphous $\mathrm{Si}_{3} \mathrm{~N}_{4}$ tissue phase regions [34-36].

The majority of current studies on nitride coatings have focused on their oxidation behaviour in air, which could be significantly different from that in water vapour at high temperature [3739]. It is generally expected that metals and ceramics show different oxidation behaviour and oxidation mechanisms in air and steam at high temperatures. For example, Kyung Tae Kim et al. found that $\mathrm{Zr}$ oxidised more rapidly in air than than in steam at $700-1200^{\circ} \mathrm{C}$ [40]. Dong Jun Park et al. reported that SiC showed two distinctly different oxidation behaviours in air and water vapour environments at $1200^{\circ} \mathrm{C}$ and $\mathrm{SiC}$ underwent weight gain and weight loss during oxidation in air and water vapour, respectively [41].

There are few studies of the oxidation behaviour of $\mathrm{ZrN}$, TiN and TiSiN coatings in a water vapour environment at high temperature, not to mention a systematically comparative study of their oxidation resistance. Thus, to find out whether nitrides might be used as effective coating materials for the protection of zirconium fuel cladding in case of LOCA, binary ZrN and TiN nitride coatings and ternary TiSiN coatings have been fabricated. The oxidation behaviour and oxidation mechanism of these nitride coatings in high temperature water vapour environment have been studied and compared.

\section{Experimental procedures}


The $\mathrm{ZrN}$ coating was deposited on $\mathrm{Zr} 2.5 \mathrm{wt} \% \mathrm{Nb}$ alloy coupons (100 x 50 x $2 \mathrm{~mm}^{3}$ ), and TiN and TiSiN coatings were deposited on silicon wafer substrates by reactive magnetron sputtering. Before deposition, the alloy substrate coupons were ground, polished and ultrasonically cleaned in acetone. The deposition took place in a Teer Coatings Ltd. UDP 350 closed field unbalanced magnetron sputtering system, described in detail elsewhere [39]. Up to three vertically mounted magnetrons $\left(300 \times 100 \mathrm{~mm}^{2}\right)$ were installed in opposed positions through the chamber walls, with a centrally mounted rotating substrate holder. The $99.5 \%$ pure zirconium (for $\mathrm{ZrN}$ coating deposition); titanium and silicon (for $\mathrm{TiN}$ and $\mathrm{TiSiN}$ coating deposition) targets were fitted to the magnetrons. Prior to deposition, the chamber was pumped down to a base pressure of below $1 \times 10^{-3} \mathrm{~Pa}$ and then backfilled to a working pressure of $0.3 \mathrm{~Pa}$ with argon. The substrates were DC sputter cleaned at a bias voltage of $-600 \mathrm{~V}$ for 15 minutes. The targets were powered by Advanced Energy Pinnacle Plus power supplies operating in pulsed DC mode at average powers ranging from $100 \mathrm{~kW}$ to $1000 \mathrm{~kW}$, pulse frequency of 100 $\mathrm{kHz}$ (duty cycle $=60 \%$ ), and a bias of $-30 \mathrm{~V}$ was applied to the substrate throughout deposition. The optical emission monitoring (OEM) system was used to control the amount of nitrogen introduced into the system during the deposition of $\mathrm{ZrN}$ and TiN films. The Ar flow rate was 20 standard cubic centimetres per minute (SCCM) and $\mathrm{N}_{2}$ was controlled using an OEM setting of $50 \%$ total metal ( $\mathrm{Zr}$ or $\mathrm{Ti}$ ) signal. Protective coating thicknesses were between 1.8 and 4.3 $\mu \mathrm{m}$, respectively.

Oxidation in steam was conducted by flowing a mixture of argon and water vapour through a universal tube furnace (Carbolite, UK) at a temperature range between 600 and $900^{\circ} \mathrm{C}$ for different times (Table 1). The argon $(0.4 \mathrm{~L} / \mathrm{min})$ first flowed through a flask containing $~ 400$ $\mathrm{ml}$ boiling water and sufficient steam was then carried by the flowing argon to the hot zone of the long and thin quartz tube where the samples were placed. The volume of the steam flowing over the surface of the sample was $1.74 \mathrm{~L} / \mathrm{min}$. In order to minimise the oxidation during 
ramping and cool down tages, the samples were placed directly inside the furnace when the temperature reached the target temperature and then taken out immediately after oxidation. $\mathrm{ZrN}$ coatings were also oxidised in air to demonstrate the difference in the oxidation mechanisms occurring between two different environments. .

The phase composition of the as-deposited and oxidised coatings was analysed by grazing incidence X-ray diffraction (GIXRD, incident angle $5^{\mathrm{o}}\left(\sim 2.4 \mu \mathrm{m}\right.$ penetration) and $2^{\mathrm{o}}(\sim 1.5$ $\mu \mathrm{m}$ penetration), Philips X'pert) using $\mathrm{Cu} \mathrm{K} \alpha$ radiation $(\lambda=1.5406 \AA)$. The cross-section of the coatings and oxides were investigated by scanning electron microscopy (SEM, FEI, Quanta 650, $20 \mathrm{KV}$ ) coupled with a focused ion beam (FIB, FEI, Quanta 3D, $30 \mathrm{kV}$ milling voltage, 1 to $7 \mathrm{nA}$ current for rough milling, $0.1 \mathrm{nA}$ for final milling). The coating surface was coated with platinum before being subjected to FIB milling to protect the coating surface from the beam damage. The thickness of the oxides was estimated from the cross-section exposed by FIB milling through the surface. To obtain the fine microstructure of the coating samples, thin lamellas of the cross-sections of the oxides were prepared by FIB using the in-situ lift-out technique and were then examined using transmission electron microscopy (TEM, FEI, Tecnai G2 20, $200 \mathrm{kV}$ ) fitted with an energy dispersive X-ray spectroscopy (EDS) system (Oxford Instruments).

\section{Results and discussion}

Figures $1 \mathrm{a}, \mathrm{b}$ and $\mathrm{c}$ show cross sectional micrographs of the as-deposited $\mathrm{ZrN}$, TiN and TiSiN coatings, respectively. The as-deposited coatings are smooth, fully dense, and well-adhered to the substrate and there is no significant roughness, porosity or cracks. The composition of the $\mathrm{ZrN}$ or TiN coatings are 50 at $\% \mathrm{Zr}$ or Ti, 50 at $\% \mathrm{~N}$, while the composition of the TiSiN coating is 10 at $\% \mathrm{Si}, 42$ at $\% \mathrm{Ti}, 48$ at $\% \mathrm{~N}$, based on the energy dispersive $\mathrm{X}$-ray spectroscopy analysis. Fig. 2 a shows the phase structure analysis of the as-deposited $\mathrm{ZrN}$, TiN and TiSiN coatings obtained using glancing angle XRD (GIXRD) with an incident angle of $5^{\circ}$. The GIXRD 
patterns show that the $\mathrm{ZrN}$ coating consists of the cubic $\mathrm{ZrN}$ phase (ICDD 01-080-3718) and has no preferred orientation. The $\mathrm{Zr}$ peaks in the traces are from the substrate material. It can be observed that the $\mathrm{ZrN}$ peaks are relatively broad, compared to the $\mathrm{Zr}$ peaks, indicating a fine grained structure. The GIXRD patterns collected from TiN and TiSiN show characteristic peaks of cubic TiN (ICDD 04-001-2272). The peaks obtained on TiSiN coating however, have low intensity, which could suggest weakly crystalline structures and are relatively broad, indicating fine grain structures. The $\mathrm{Si}_{3} \mathrm{~N}_{4}$ phase is not detected due to its amorphous nature [32-33]. Fig. 2 b shows the high resolution transmission electron microscopy (HRTEM) image of as-deposited TiSiN indicating that the TiN nanocrystals are partially enveloped by amorphous $\mathrm{Si}_{3} \mathrm{~N}_{4}$ tissue phases. The bright spots and dim patterns in the Fast Fourier Transformation (FFT) spectra (insert in Fig. 2 b) reveal the coexistence of nanocrystals and an amorphous phase, which is in agreement with HRTEM observations.

Fig.3 shows the cross-sectional SEM images of the nitride coatings after water vapour oxidation at different temperatures for $1 \mathrm{~h}$. After oxidation at $600^{\circ} \mathrm{C}$ for $1 \mathrm{~h}$, the $\mathrm{ZrN}$ is heavily oxidized, and the oxide layer reveals pores and a greater number of cracks, as shown in Fig.3 a. The oxidation product is $\mathrm{ZrO}_{2}$, confirmed by the XRD pattern in Fig.4. And the reaction between $\mathrm{MN}(\mathrm{M}=\mathrm{Zr}$, Ti or $\mathrm{Si})$ and water vapour could be written as follows:

$$
M N+H_{2} \mathrm{O}=a M O_{2}+b N_{2}+c H_{2}
$$

Moreover, approximately half of the $\mathrm{ZrN}$ coating has been consumed and the thickness of the oxide layer is about $2.6 \mu \mathrm{m}$. The oxidation resistance of $\mathrm{TiN}$ is better than that of $\mathrm{ZrN}$ as the oxide formed on TiN after oxidation in steam at $600^{\circ} \mathrm{C}$ for $1 \mathrm{~h}$ is around $100 \mathrm{~nm}$ thick (not shown here), which is in accordance with that in a high temperature air environment [25]. Increasing the oxidation temperature to $900^{\circ} \mathrm{C}$ for $1 \mathrm{~h}$, the $\mathrm{TiN}$ is heavily oxidized with approximately half of the coating consumed. The oxide scale on top of the TiN coating is about $5.7 \mu \mathrm{m}$ thick. A great number of pores are visible across the $\mathrm{TiO}_{2}$ scale (confirmed by XRD in 
Fig.4), while the oxide scale has not spalled from the TiN coating. By adding 10 at\% Si into TiN, the TiSiN coating consisting of TiN crystalline regions partially enveloped by $\mathrm{Si}_{3} \mathrm{~N}_{4}$ shows enhanced oxidation resistance, compared to the TiN coating as the oxide scale formed on the TiSiN is only $700 \mathrm{~nm}$ after steam oxidation at $900^{\circ} \mathrm{C}$ for 1 hour, as shown in Fig. $3 \mathrm{c}$. Accordingly, the oxide layer on the TiSiN coating containing $\mathrm{SiO}_{2}$ and $\mathrm{TiO}_{2}$ (confirmed by the XRD pattern in Fig.4 and below Fig.5c) is dense and less defective than that of the $\mathrm{TiO}_{2}$ scale formed on the TiN sample. The addition of Si into TiN decreases the amount of defects across the related oxide scale and, thereby, contributes to the enhancement of oxidation resistance. Thus, the oxidation resistance of these three nitride coatings in a high temperature water vapour environment follows the order: $\mathrm{TiSiN}>\mathrm{TiN}>\mathrm{ZrN}$.

In order to get more detailed information on the thin oxide scales formed on the nitride coatings, thin lamellas of the cross-sections of the oxides were prepared by FIB and were examined by TEM. Fig.5 shows the cross-sectional TEM images of oxide scales on $\mathrm{ZrN}$ (Fig.5 a) and TiSiN (Fig. 5 b) coatings after steam oxidation. It can be seen that the non-interconnected cracks and pores are distributed uniformly across the $\mathrm{ZrO}_{2}$ oxide layer on $\mathrm{ZrN}$ and there is no visible vertical cracking to the coating/substrate interface, indicated as red arrows in Fig.5 a, which was also reported by our previous work [39]. No vertical cracks are visible at the coating/substrate interface, suggesting that the oxide scale is not prone to spalling off the underlying coating. These pores appearing throughout the oxide layer may have developed as a result of the entrapment of the gaseous reaction by-products, $\mathrm{N}_{2}$ and $\mathrm{H}_{2}$, which could not diffuse through the oxide layer [42]. After steam oxidation of $\mathrm{TiSiN}$ coating at $900^{\circ} \mathrm{C}$ for 1 hour, the oxide scale containing a mixture of $\mathrm{SiO}_{2}$ and $\mathrm{TiO}_{2}$ (confirmed by XRD and EDS mappings in Fig.4 and Fig.5c) is thin and dense and only trace amounts of pores are observed, as shown in Fig.5 b, and thereby the scale contributes to the enhancement of oxidation resistance. 
In order to compare oxidation performance and further study the oxidation mechanisms of nitrides in steam and air environments at high temperature, the $\mathrm{ZrN}$ coatings were exposed not only in a steam environment but also in air environment at $600^{\circ} \mathrm{C}$. Fig. 6 shows the change in oxide thickness as a function of time for $\mathrm{ZrN}$ oxidised in air and steam at $600^{\circ} \mathrm{C}$. The rate changes of the $\mathrm{ZrO}_{2}$ layer formation after oxidation in air and steam reveal classical parabolic curves (air, $\mathrm{R}^{2}, 0.99 ; \mathrm{k}, 1.5 \times 10^{-13} \mathrm{~m}^{2} \mathrm{~s}^{-1}$ ), (steam, $\mathrm{R}^{2}, 0.98 ; \mathrm{k}, 1.5 \times 10^{-11} \mathrm{~m}^{2} \mathrm{~s}^{-1}$ ), due to the increased diffusion distance for oxidising species migrating through the growing $\mathrm{ZrO}_{2}$ layer to the $\mathrm{ZrO}_{2} / \mathrm{ZrN}$ reaction interface. However, the parabolic rate constant of $\mathrm{ZrN}$ at $600{ }^{\circ} \mathrm{C}$ oxidizing in water vapour is approximately 100 times faster than that in air. The reason can be mainly attributed to the noted variation in oxide microstructures, i.e., greater porosity and cracking of the $\mathrm{ZrO}_{2}$ formed in the water vapour environment, as shown in Fig.5 a and Fig. 6 b. The large number of cracks and pores in $\mathrm{ZrO}_{2}$ (Fig.5a) after steam oxidation can contribute to the transportation of oxidizing species to the $\mathrm{ZrN} / \mathrm{ZrO}_{2}$ reaction interface, and thereby enhance the recession of the $\mathrm{ZrN}$ coating in the high temperature steam environment [39]. It is suggesting that the potential materials for accident tolerant fuel applications may degrade faster than the expected performance in the widely studied air environment at high temperature.

The oxidation studies of nitride coatings showed that the factors affecting oxidation resistance of these coatings are the thermal stability (i.e. the tendency to decompose upon thermal annealing) of the nitrides and the microstructure and composition of the oxide formed on the top surface of the film [21]. $\mathrm{Si}_{3} \mathrm{~N}_{4}$ has been reported to be more stable than other MeN phases $(\mathrm{Me}=\mathrm{Ti}, \mathrm{Zr})[21]$ and $\mathrm{TiN}$ more stable than $\mathrm{ZrN}$ at high temperature in air [25]. The $\mathrm{Si}_{3} \mathrm{~N}_{4}$ attributes its great thermal stability and also its amorphous structure, which lacks grain boundaries that can serve as fast diffusion pathways. In steam oxidation the water molecules are dissociated to $\mathrm{OH}^{-1}$ and $\mathrm{H}^{+}$, and the $\mathrm{O}-\mathrm{H}$ bonds can be further broken to form free oxygen ions to serve as the oxidizing species [43]. Then the $\mathrm{MN}$ nitride ( $\mathrm{M}=\mathrm{Ti}, \mathrm{Zr}, \mathrm{Si})$ can easily react 
with the oxidizing species (according to the above reaction equation) at high temperature. This way, the $\mathrm{MO}_{2}(\mathrm{M}=\mathrm{Ti}, \mathrm{Zr}, \mathrm{Si})$ metal oxide is formed and thickens with time. This thick oxide layer formed on top of the nitride coating can serve as a barrier layer to inward diffusion of the oxidising species. It was reported that some nitrides oxidized at high temperatures in air form dense metal oxide scales such as $\mathrm{SiO}_{2}$ or $\mathrm{Al}_{2} \mathrm{O}_{3}$. Other nitrides could form volatile oxides, which escape from the oxide scale and cannot serve as a barrier layer during annealing, e.g. WOx, MoOx. In other cases, metal oxides have porous microstructures, which lowers its efficiency as a barrier layer, e.g. $\mathrm{ZrO}_{2}[21,38,44]$.

After oxidation in the water vapour environment, the $\mathrm{ZrO}_{2}$ scale formed on the $\mathrm{ZrN}$ is full of pores and cracks and the $\mathrm{TiO}_{2}$ scale formed on the $\mathrm{TiN}$ also shows a porous structure. These cracked and porous oxide layers can only prohibit the transporting of the oxidizing species to a certain extent. The oxide scale formed on the TiSiN, on the other hand, was relatively dense, and therefore served as a better barrier layer for inward diffusion of the oxidising species. Moreover, it is proven that the intrinsic oxygen diffusion coefficient (ODC) of $\mathrm{SiO}_{2}$ is lower than that of $\mathrm{TiO}_{2}$ and the $\mathrm{ODC}$ of $\mathrm{TiO}_{2}$ is lower than that of $\mathrm{ZrO}_{2}$ at high temperatures [45]. Thus, the TiSiN coating has better oxidation resistance than $\mathrm{TiN}$ and $\mathrm{ZrN}$ coatings in the high temperature steam environment.

\section{Conclusions}

In this work, the oxidation mechanisms of $\mathrm{ZrN}$, TiN and $\mathrm{TiSiN}$ coatings deposited by magnetron sputtering have been investigated in a high temperature steam environment. It was found that the TiSiN has significantly improved oxidation resistance, in comparison to $\mathrm{ZrN}$ or TiN. This could be attributed to the Si dopant into the TiN resulting in the as-deposited TiSiN microstructure consisting of TiN nanocrystals partially enclosed within amorphous $\mathrm{Si}_{3} \mathrm{~N}_{4}$ tissue phases. Moreover, these dense metal oxides formed on top of TiSiN upon steam oxidation served as a barrier layer to inward diffusion of the oxidising species. In contrast, porous $\mathrm{ZrO}_{2}$ 
or $\mathrm{TiO}_{2}$ scales formed on top of $\mathrm{ZrN}$ or $\mathrm{TiN}$ could only prohibit the transport of oxidising species to a certain extent. Finally, the intrinsic oxygen diffusion coefficient of $\mathrm{SiO}_{2}$ is lower at high temperatures than that of $\mathrm{ZrO}_{2}$ and $\mathrm{TiO}_{2}$, which in turn makes the TiSiN coating more oxidation resistant than $\mathrm{ZrN}$ or $\mathrm{TiN}$.

\section{References:}

[1] D.J. Park, H.G. Kim, J.Y. Park, Y.I. Jung, J.H. Park, Y.H. Koo, A study of the oxidation of FeCrAl alloy in pressurized water and high-temperature steam environment, Corrosion Science, 94 (2015) 459-465.

[2] M. Moalem, D.R. Olander, Oxidation of Zircaloy by steam, Journal of Nuclear Materials, 182 (1991) 170-194.

[3] M. Steinbrück, Prototypical experiments relating to air oxidation of Zircaloy-4 at high temperatures, Journal of Nuclear Materials, 392 (2009) 531-544.

[4] M. Steinbrück, M. Böttcher, Air oxidation of Zircaloy-4, M5 ${ }^{\circledR}$ and ZIRLO ${ }^{\mathrm{TM}}$ cladding alloys at high temperatures, Journal of Nuclear Materials, 414 (2011) 276-285. [5] C. Duriez, M. Steinbrück, D. Ohai, T. Meleg, J. Birchley, T. Haste, Separate-effect tests on zirconium cladding degradation in air ingress situations, Nuclear Engineering and Design, 239 (2009) 244-253.

[6] X. Zhang, B. Zhang, Y. Mu, S. Shao, C.D. Wick, B.R. Ramachandran, W.J. Meng, Mechanical failure of metal/ceramic interfacial regions under shear loading, Acta Materialia, 138 (2017) 224-236.

[7] J. Gerth, U. Wiklund, The influence of metallic interlayers on the adhesion of PVD TiN coatings on high-speed steel, Wear, 264 (2008) 885-892.

[8] E. Bemporad, M. Sebastiani, C. Pecchio, S. De Rossi, High thickness Ti/TiN multilayer thin coatings for wear resistant applications, Surface and Coatings Technology, 201 (2006) 2155-2165. 
[9] J.H. Huang, C.H. Ma, H. Chen, Effect of Ti interlayer on the residual stress and texture development of TiN thin films, Surface and Coatings Technology, 200 (2006) 5937-5945

[10] K.A. Terrani, C.M. Parish, D. Shin, B.A. Pint, Protection of zirconium by alumina- and chromia-forming iron alloys under high-temperature steam exposure, Journal of Nuclear Materials, 438 (2013) 64-71.

[11] D. Jin, F. Yang, Z. Zou, L. Gu, X. Zhao, F. Guo, P. Xiao, A study of the zirconium alloy protection by $\mathrm{Cr}_{3} \mathrm{C}_{2}-\mathrm{NiCr}$ coating for nuclear reactor application, Surface and Coatings Technology, 287 (2016) 55-60.

[12] F. Khatkhatay, L. Jiao, J. Jian, W. Zhang, Z. Jiao, J. Gan, H. Zhang, X. Zhang, H. Wang, Superior corrosion resistance properties of TiN-based coatings on Zircaloy tubes in supercritical water, Journal of Nuclear Materials, 451 (2014) 346-351.

[13] Hyun-Gil Kim, Yang-Il Jung, Dong-Jun Park, Jeong-Yong Park, Yang-Hyun Koo, Hightemperature oxidation behaviour of Cr-coated Zirconium alloy, TopFuel 2013, Charlotte, North Carolina, September 15-19, 2013, 2013, pp. 842-846.

[14] J. Bischoff, C. Delafoy, C. Vauglin, P. Barberis, C. Roubeyrie, D. Perche, D. Duthoo, F. Schuster, J.C. Brachet, E. W. Schweitzer, K. Nimishakaviet, "AREVA NP's enhanced accident-tolerant fuel developments: Focus on Cr-coated M5 cladding, Nuclear Engineering and Technology, 50 (2018) 223-228.

[15] R. Oelrich, S. Ray, Z. Karoutas, P. Xu, J. Romero, H. Shah, E. Lahoda, F. Boylan, Overview of Westinghouse Lead Accident Tolerant Fuel Program, in Proceedings of the TOP FUEL 2018 conference, Prague, Czech Republic, 30 Sept-04 Oct 2018, 2018, A0036.

[16] K.A. Terrani, "Accident tolerant fuel cladding development: Promise, status, and challenges," Journal of Nuclear Materials, 501 (2018) 13-30.

[17] C. Tang, M. Stueber, H. J. Seifert, M. Steinbrueck, Protective coatings on zirconium-based alloys as accident-Tolerant fuel (ATF) claddings, Corrosion Reviews, 35 (2017) 141-165. 
[18] P.H. Mayrhofer, C. Mitterer, L. Hultman, H. Clemens, Microstructural design of hard coatings, Progress in Materials Science, 51 (2006) 1032-1114.

[19] H. Gleiter, Nanostructured materials basic concepts and microstructure, Acta Materialia, $48(2000) 1-29$.

[20] B.R.H.a.J. Patscheider, From Alloying to Nanocomposites-Improved Performance of Hard Coatings, Advanced Engineering Materials, 2 (2000) 247-259.

[21] J. Musil, Hard nanocomposite coatings: Thermal stability, oxidation resistance and toughness, Surface and Coatings Technology, 207 (2012) 50-65.

[22] M. Chhowalla, H.E. Unalan, Thin films of hard cubic $\mathrm{Zr}_{3} \mathrm{~N}_{4}$ stabilized by stress, Nature materials, 4 (2005) 317-322.

[23] E. Budke, J. Krempel-Hesse, H. Maidhof, H. Schüssler, Decorative hard coatings with improved corrosion resistance, Surface and Coatings Technology, 112 (1999) 108-113.

[24] C.S. Chen, C.P. Liu, C.Y.A. Tsao, H.G. Yang, Study of mechanical properties of PVD $\mathrm{ZrN}$ films, deposited under positive and negative substrate bias conditions, Scripta Materialia, $51(2004) 715-719$.

[25] X.M. Xu, J. Wang, Q.Y. Zhang, Oxidation Behaviour of TiN/ZrN multilayers annealed in air, Thin Solid Films, 516 (2008) 1025-1028.

[26] Y.C. Chim, X.Z. Ding, X.T. Zeng, S. Zhang, Oxidation resistance of TiN, CrN, TiAlN and CrAlN coatings deposited by lateral rotating cathode arc, Thin Solid Films, 517 (2009) 4845-4849.

[27] S.-K. Tien, J.-G. Duh, J.-W. Lee, Oxidation Behaviour of sputtered CrN/AIN multilayer coatings during heat treatment, Surface and Coatings Technology, 201 (2007) 5138-5142.

[28] U. M. Nosea, M. Zhoub, T. Nagaec, T. Maed, M. Yokotaa, S. Sajie, Properties of Zr-SiN coatings prepared by RF reactive sputtering, Surface and Coatings Technology, 132 (2000) 163-168. 
[29] Q.G. Zhou, X.D. Bai, X.Y. Xue, Y.H. Ling, X.W. Chen, J. Xu, D.R. Wang, The influence of $\mathrm{Y}$ ion implantation on the oxidation behaviour of $\mathrm{ZrN}$ coating, Vacuum, 76 (2004) 517-521. [30] Z. Lei, Y. Liu, F. Ma, Z. Song, Y. Li, Oxidation resistance of TiAlN/ZrN multilayer coatings, Vacuum, 127 (2016) 22-29.

[31] Z. Wu, Z. Qi, D. Zhang, Z. Wang, Evolution of the microstructure and oxidation resistance in co-sputtered Zr-Y-N coatings, Applied Surface Science, 321 (2014) 268-274.

[32] Q.M. Wang, K.H. Kim, Microstructural control of $\mathrm{Cr}-\mathrm{Si}-\mathrm{N}$ films by a hybrid arc ion plating and magnetron sputtering process, Acta Materialia, 57 (2009) 4974-4987.

[33] N. Ghafoor, I. Petrov, D.O. Klenov, B. Freitag, J. Jensen, J.E. Greene, L. Hultman, M. Odén, Self-organized anisotropic ( $\mathrm{Zr} 1-\mathrm{x}$ Si x )N y nanocomposites grown by reactive sputter deposition, Acta Materialia, 82 (2015) 179-189.

[34] J. Musil, G. Remnev, V. Legostaev, V. Uglov, A. Lebedynskiy, A. Lauk, J. Procházka, S. Haviar, E. Smolyanskiy, Flexible hard Al-Si-N films for high temperature operation, Surface and Coatings Technology, 307 (2016) 1112-1118.

[35] J. Musil, M. Šašek, P. Zeman, R. Čerstvý, D. Heřman, J.G. Han, V. Šatava, Properties of magnetron sputtered Al-Si-N thin films with a low and high Si content, Surface and Coatings Technology, 202 (2008) 3485-3493.

[36] K.A. Kuptsov, P.V. Kiryukhantsev-Korneev, A.N. Sheveyko, D.V. Shtansky, Structural transformations in TiAlSiCN coatings in the temperature range $900-1600^{\circ} \mathrm{C}$, Acta Materialia, 83 (2015) 408-418.

[37] R.W. Harrison, W.E. Lee, N. Jacobson, Mechanism and Kinetics of Oxidation of ZrN Ceramics, Journal of the American Ceramic Society, 98 (2015) 2205-2213.

[38] Z.B. Qi, Z.T. Wu, H.F. Liang, D.F. Zhang, J.H. Wang, Z.C. Wang, In situ and ex situ studies of microstructure evolution during high-temperature oxidation of $\mathrm{ZrN}$ hard coating, Scripta Materialia, 97 (2015) 9-12. 
[39] Z. Gao, Y. Chen, J. Kulczyk-Malecka, P. Kelly, Y. Zeng, X. Zhang, C. Li, H. Liu, N. Rohbeck, P. Xiao, Comparison of the oxidation behaviour of a zirconium nitride coating in water vapour and air at high temperature, Corrosion Science, (2018) 242-251.

[40] K.P. Kyung Tae Kim The high-temperature oxidation kinetics of Zr-alloy claddings in air and steam, Transactions of the Korean Nuclear Society Autumn Meeting, (2013) 24-25.

[41] D.J. Park, Y.I. Jung, H.G. Kim, J.Y. Park, Y.H. Koo, Oxidation behavior of silicon carbide at $1200^{\circ} \mathrm{C}$ in both air and water-vapor-rich environments, Corrosion Science, 88 (2014) 416422.

[42] Kurt A. Terrani, Bruce A. Pint, Chad M. Parish, Chinthaka M. Silva, Lance L. Snead, and Y. Katoh, Silicon, Carbide Oxidation in Steam up to $2 \mathrm{MPa}$, The American Ceramic Society, 97 (2014) 2331-2352 .

[43] Langli Luo, Pengfei Yan, Lianfeng Zou, Daniel K. Schreiber, Zhijie Xu and Chongmin Wang, Atomic origins of water-vapour-promoted alloy oxidation, Nature materials, 17 (2018) 514-518.

[44] P. Zeman, J. Musil, Difference in high-temperature oxidation resistance of amorphous ZrSi-N and W-Si-N films with a high Si content, Applied Surface Science, 252 (2006) 83198325.

[45] Y. Zeng, D. Wang, X. Xiong, X. Zhang, P.J. Withers, W. Sun, M. Smith, M. Bai, P. Xiao, Ablation-resistant carbide $\mathrm{Zr}_{0.8} \mathrm{Ti}_{0.2} \mathrm{C}_{0.74} \mathrm{~B}_{0.26}$ for oxidizing environments up to 3,000 degrees C, Nature communications, 8 (2017) 15836.

\section{List of figure captions:}

Figure 1: Cross-sectional SEM images of as-deposited $\mathrm{ZrN}$ coating (a), TiN (tilt angle $52^{\circ}$ ) (b) and TiSiN (tilt angle $52^{\circ}$ ) (c). 
Figure 2: The GXRD patterns of (a) as-deposited $\mathrm{ZrN}$, TiN and TiSiN coatings; (b) HRTEM image of as-deposited TiSiN coating, inset is the FFT spectra of (b).

Figure 3: Cross-sectional SEM image of the coatings after steam oxidation at different temperatures for 1 hour: (a) $\mathrm{ZrN}$ at $600^{\circ} \mathrm{C}$ (tilt angle $52^{\circ}$ ); (b) $\mathrm{TiN}$ at $900^{\circ} \mathrm{C}$; (c) $\mathrm{TiSiN}$ at $900^{\circ} \mathrm{C}$ (tilt angle $52^{\circ}$ ).

Figure 4: The GIXRD patterns of oxidized $\mathrm{ZrN}$ at $600^{\circ} \mathrm{C}$, $\mathrm{TiN}$ at $900^{\circ} \mathrm{C}$ and $\mathrm{TiSiN}$ at $900^{\circ} \mathrm{C}$ for $1 \mathrm{~h}$ in steam environment.

Figure 5: (a) Cross-sectional TEM image of the $\mathrm{ZrN}$ coating after steam oxidation at $600^{\circ} \mathrm{C}$ for 1 hour; (b) Cross-sectional BF STEM images of TiSiN coating after steam oxidation at $900^{\circ} \mathrm{C}$ for 1 hour; (c) EDS-STEM elemental maps of image in (b).

Figure 6: Change in oxide thickness of oxidized $\mathrm{ZrN}$ at $600^{\circ} \mathrm{C}$ air and steam environment as a function of time; (b) Cross-sectional TEM image of the $\mathrm{ZrN}$ coating after air oxidation at $600^{\circ} \mathrm{C}$ for 1 hour.

\section{Table}

Table 1 The oxidation testing conditions for $\mathrm{ZrN}$, TiN and TiSiN coatings 

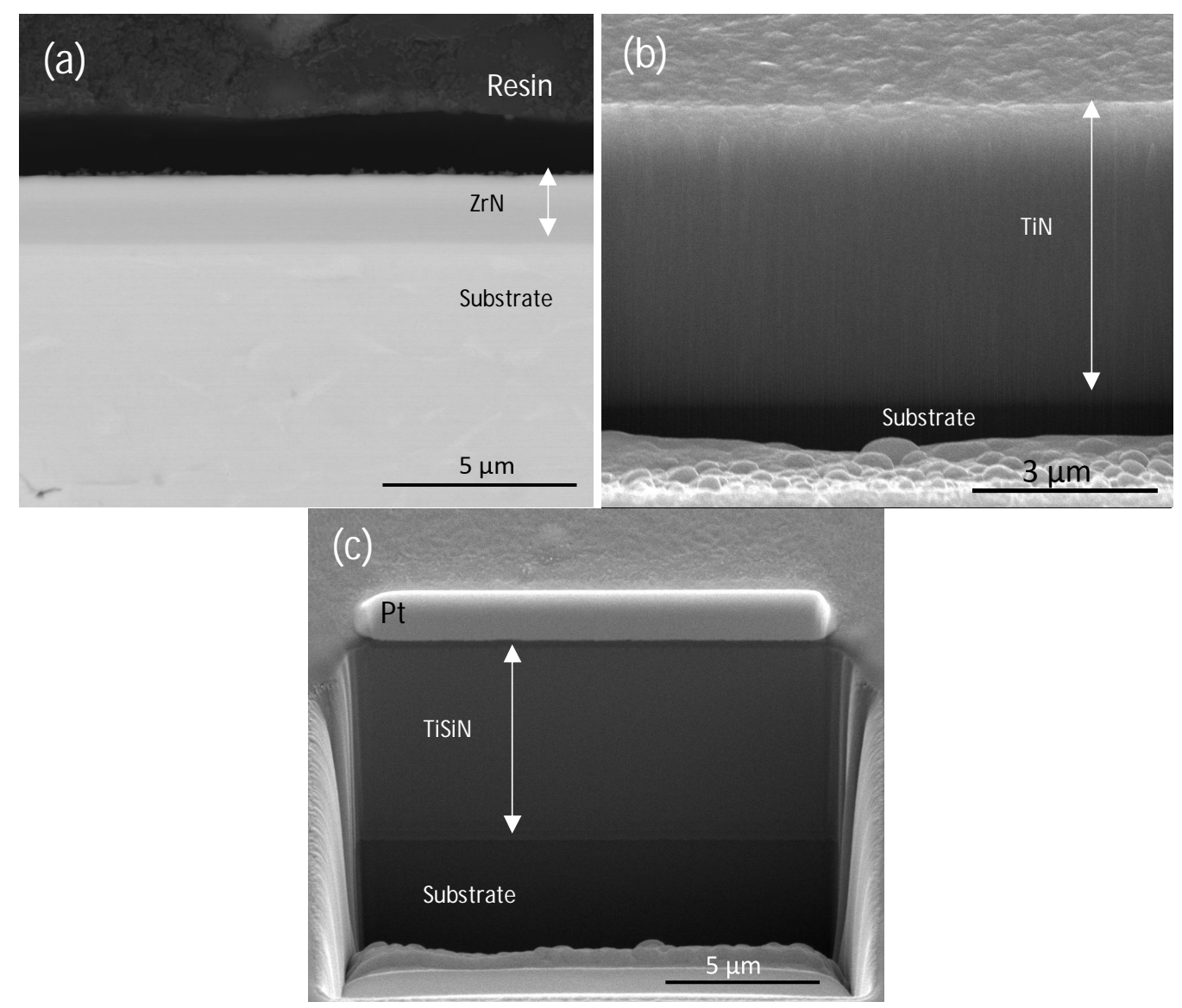

Fig. 1 Cross-sectional SEM images of as-deposited coatings. (a)ZrN, (b)TiN (tilting $52^{\circ}$ ), (c) TiSiN (tilting $52^{\circ}$ ). 

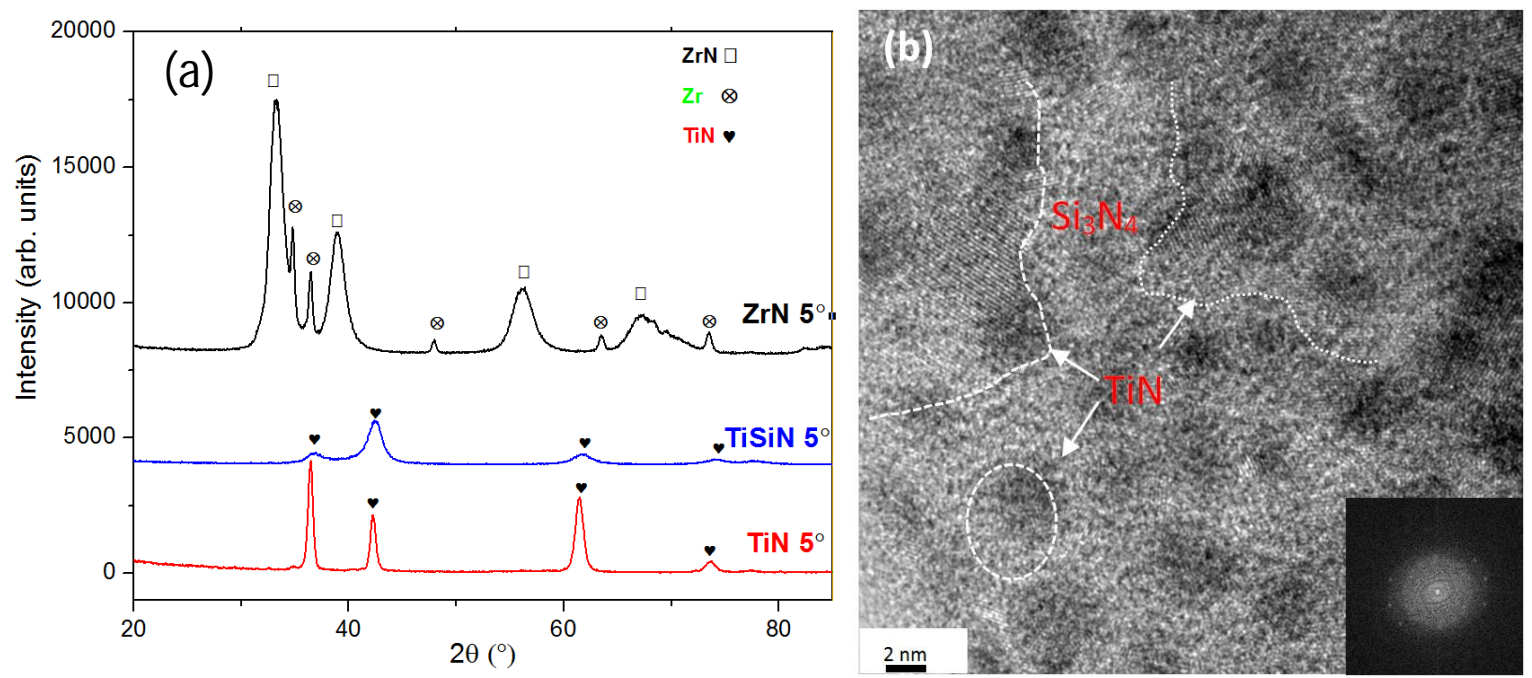

Fig.2 (a) The GIXRD patterns of as-deposited ZrN, TiN, and TiSiN coatings; (b) HRTEM image of as-deposited TiSiN coating, inset is the FFT spectra of (b). 


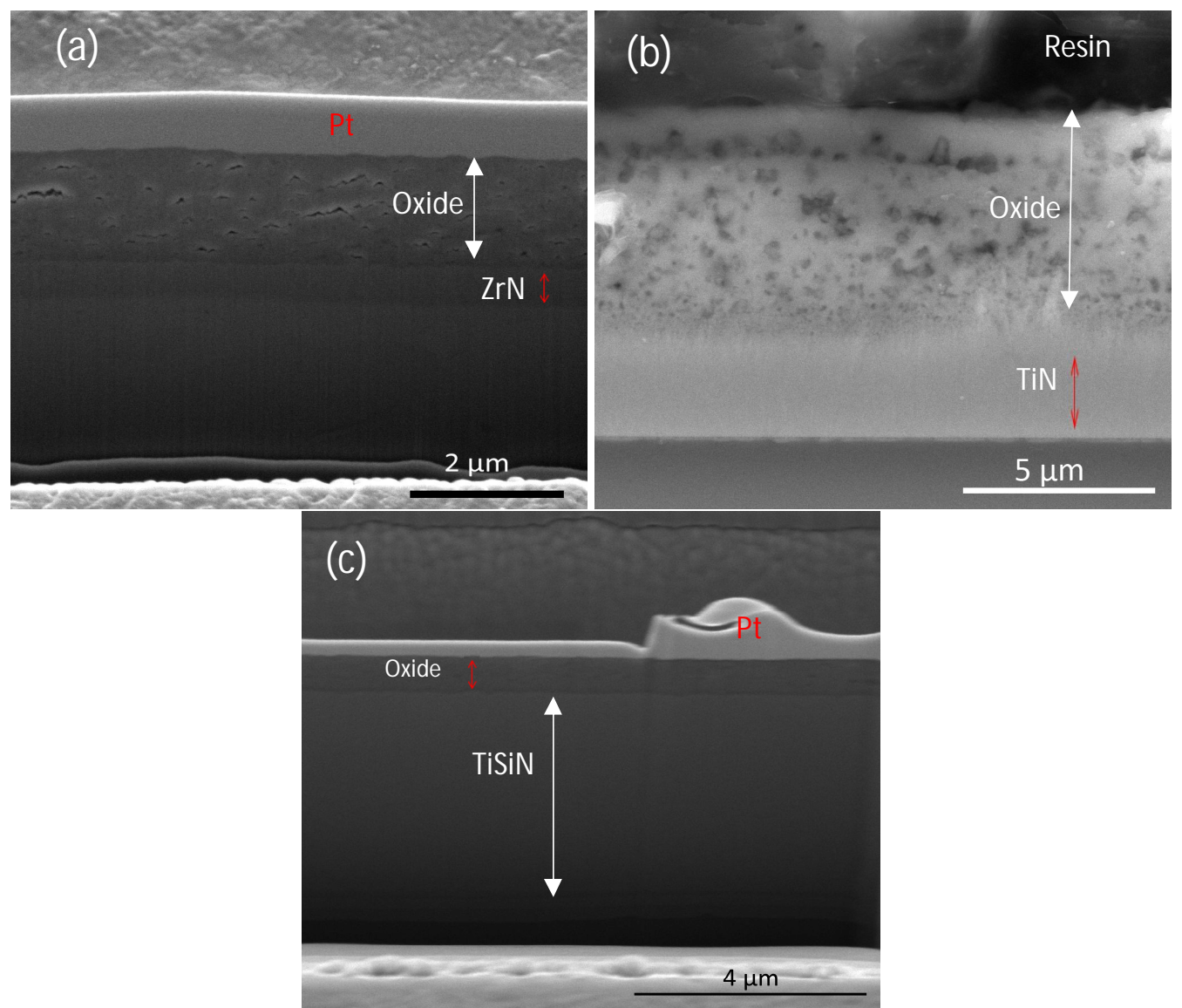

Fig. 3 Cross-sectional SEM images of coatings after steam oxidation at different temperature for 1 hour. (a) $\mathrm{ZrN}, 600^{\circ} \mathrm{C}$ (Tilting $52^{\circ}$ ); (b) $\mathrm{TiN}, 900^{\circ} \mathrm{C}$; (c) $\operatorname{TiSiN}, 900^{\circ} \mathrm{C}$ (Tilting $52^{\circ}$ ). 


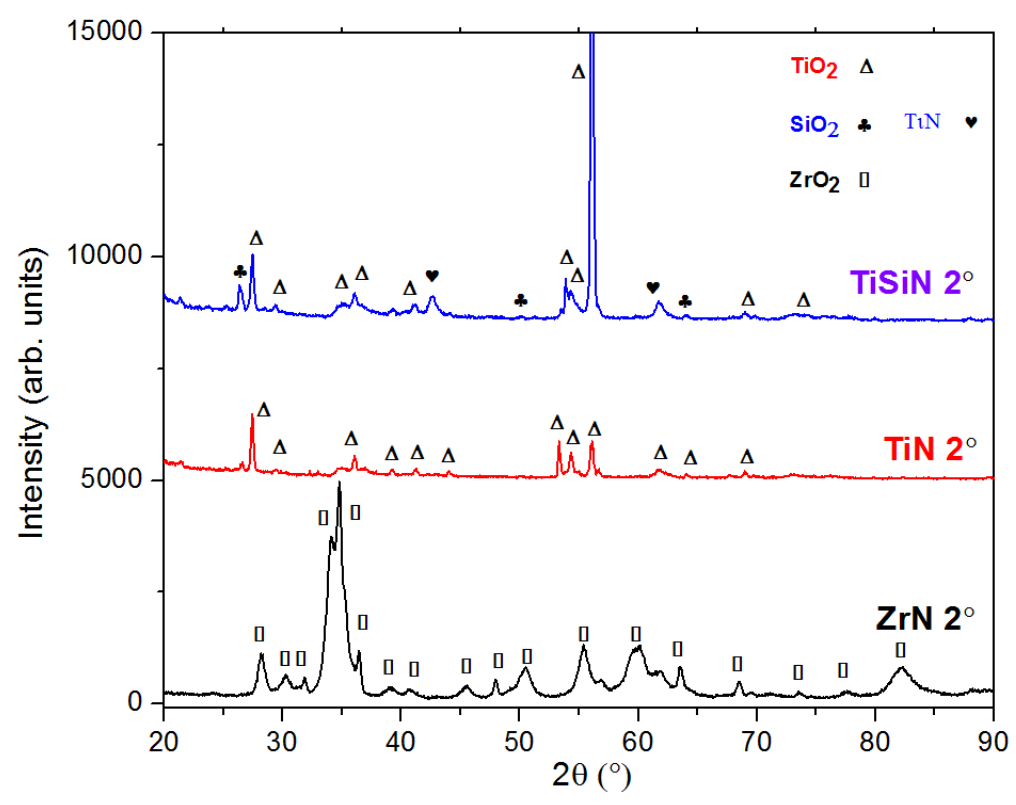

Fig.4 The GIXRD patterns of oxidized ZrN at $600^{\circ} \mathrm{C}$ for $1 \mathrm{~h}$, TiN at $900^{\circ} \mathrm{C}$ for $1 \mathrm{~h}$ and TiSiN at $900^{\circ} \mathrm{C}$ for $1 \mathrm{~h}$ in steam environment. 


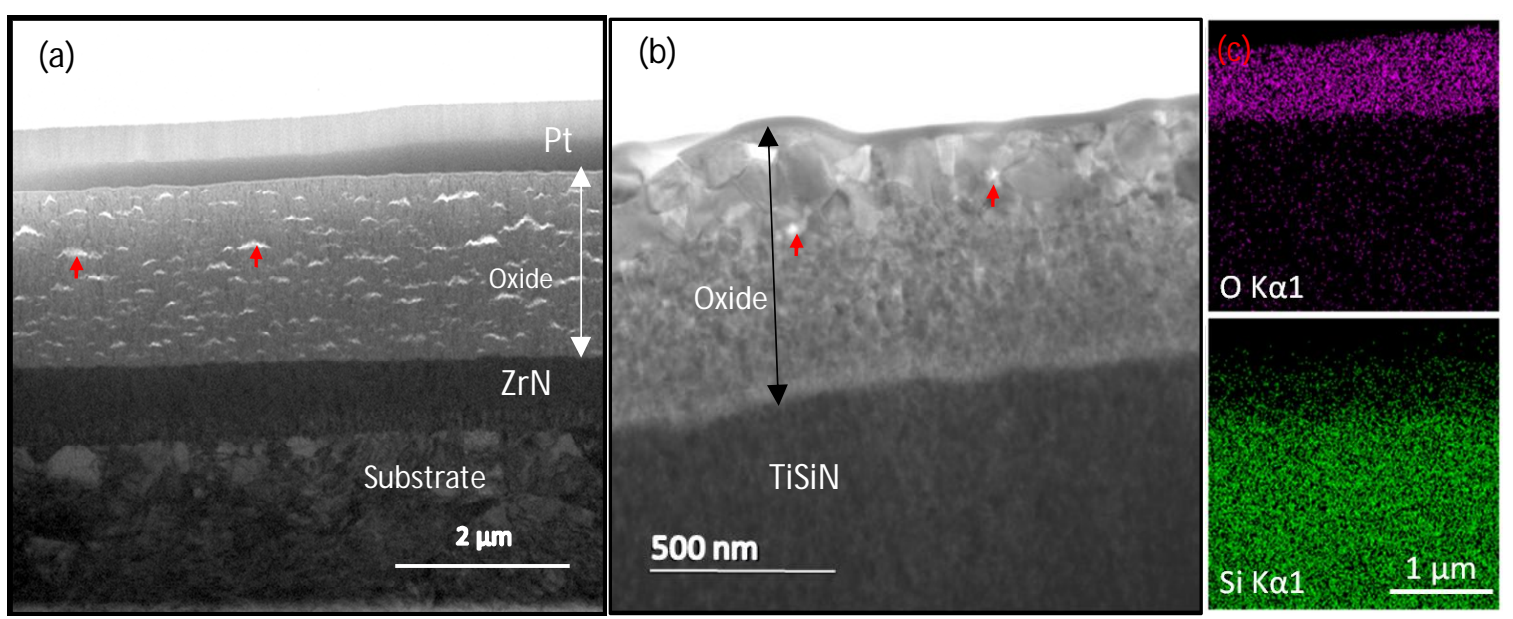

Fig. 5 (a) Cross-sectional TEM image of the ZrN coating after steam oxidation at $600^{\circ} \mathrm{C}$ for 1 hour; (b) Cross-sectional BF STEM images of TiSiN coating after steam oxidation at $900^{\circ} \mathrm{C}$ for 1 hour; (c) EDS-STEM elemental maps of image in (b). 

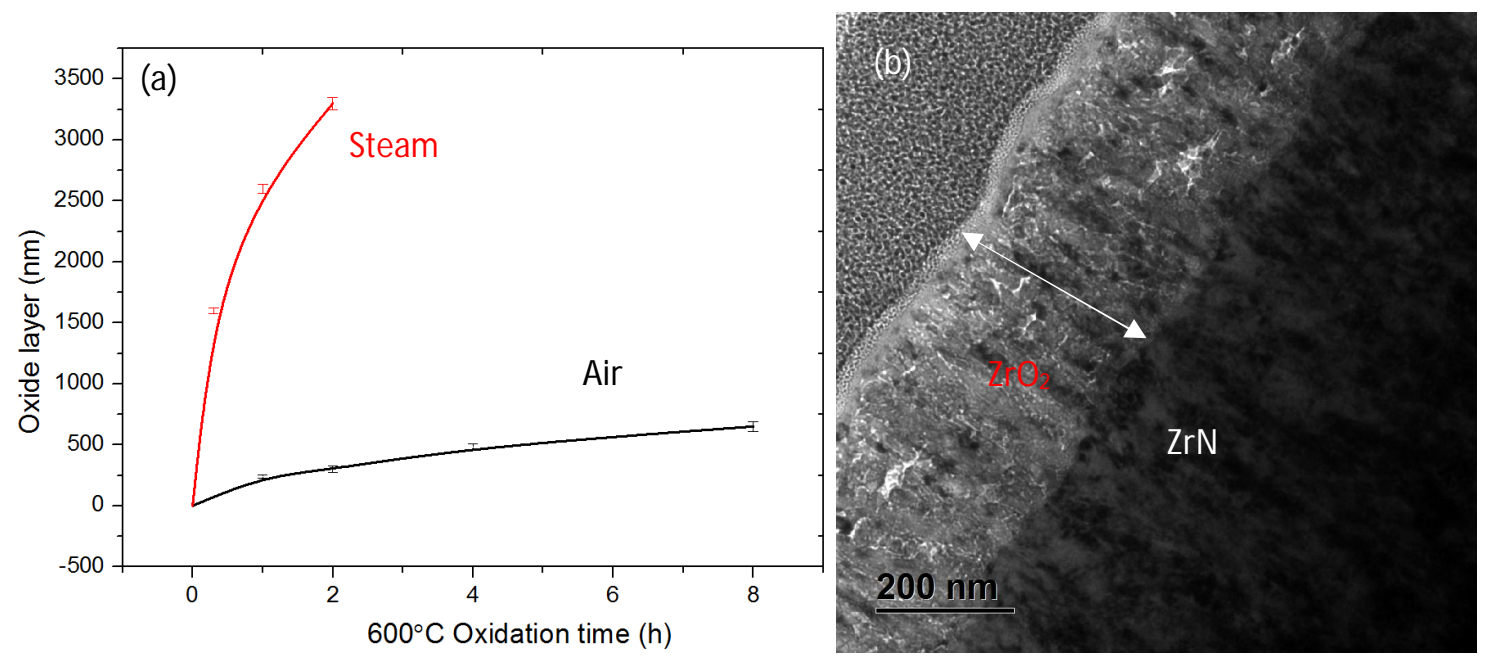

Fig. 6 (a) Change in oxide thickness of oxidized $\mathrm{ZrN}$ at $600^{\circ} \mathrm{C}$ air and steam environment as a function of time; (b) Cross-sectional TEM image of the ZrN coating after air oxidation at $600^{\circ} \mathrm{C}$ for 1 hour.

Table 1 The oxidation testing condition of ZrN, TiN and TiSiN coatings 


\begin{tabular}{|c|c|c|c|c|c|c|c|c|c|}
\hline \multirow{2}{*}{$\begin{array}{c}\text { Testin } \\
\text { g } \\
\text { numb } \\
\text { er }\end{array}$} & \multicolumn{3}{|c|}{$\mathrm{ZrN}$ on $\mathrm{ZrNb}$ alloy substrate } & \multicolumn{3}{|c|}{ TiN on Si wafer } & \multicolumn{3}{|c|}{ TiSiN on Si wafer } \\
\hline & $\begin{array}{l}\text { Oxidation } \\
\text { time (h) }\end{array}$ & $\begin{array}{l}\text { Temperat } \\
\text { ure }\left({ }^{\circ} \mathrm{C}\right)\end{array}$ & $\begin{array}{c}\text { Atmosph } \\
\text { ere }\end{array}$ & $\begin{array}{l}\text { Oxidati } \\
\text { on time } \\
\text { (h) }\end{array}$ & $\begin{array}{l}\text { Temperat } \\
\text { ure }\left({ }^{\circ} \mathrm{C}\right)\end{array}$ & $\begin{array}{c}\text { Atmosph } \\
\text { ere }\end{array}$ & $\begin{array}{l}\text { Oxidati } \\
\text { on time } \\
\text { (h) }\end{array}$ & $\begin{array}{l}\text { Temperat } \\
\text { ure }\left({ }^{\circ} \mathrm{C}\right)\end{array}$ & $\begin{array}{c}\text { Atmosph } \\
\text { ere }\end{array}$ \\
\hline 1 & $1 \mathrm{~h} / 2 \mathrm{~h}$ & 600 & steam & $1 \mathrm{~h}$ & 600 & steam & $1 \mathrm{~h}$ & 900 & steam \\
\hline 2 & $\begin{array}{c}1 \mathrm{~h} / 2 \mathrm{~h} / 4 \mathrm{~h} / \\
8 \mathrm{~h}\end{array}$ & 600 & air & $1 \mathrm{~h}$ & 900 & steam & & & \\
\hline
\end{tabular}

